\title{
The Potential Impact of Magnesium Supplementation on Cisplatin-Induced Nephrotoxicity in Adult Male Albino Rats
}

\author{
Wafaa Ibrahim Soliman and Nashwa Mohamad Mohamad Shalaby ${ }^{1}$
}

1 Department of Forensic Medicine and Clinical Toxicology, Faculty of Medicine, Zagazig University, Al sharqia , Egypt.

\begin{abstract}
Background: Cisplatin has been considered one of the most effective chemotherapeutic agents. It is associated with numerous toxicities at therapeutic doses like ototoxicity, gastrotoxicity, myelosuppression, allergic reactions and nephrotoxicity. The synergistic effects of Cisplatin and magnesium deficiency are believed to contribute to renal dysfunction. Aim:The aim of this study was to study the nephrotoxicity of cisplatin and evaluate potential impact of magnesium supplementation on such toxicity. Materials and Methods: Thirty-two adult male albino rats were divided into four equal groups. Group I served as (Control group). Group II (magnesium treated group) received single injection of magnesium sulphate $(90 \mathrm{mg} / \mathrm{kg}$ ), Groups III (Cisplatin treated group) received single injection of $5 \mathrm{mg} / \mathrm{kg}$ body weight of cisplatin and Group IV (Cisplatinand magnesium treated group) received single injection of $90 \mathrm{mg} / \mathrm{kg}$ magnesium sulphate and $5 \mathrm{mg}$ of cisplatin. After 14 days,biochemical parameters in serum were studied: creatinine,BUN, magnesium andinflammatory marker (IL-6) levels.Kidneyswere examined by light microscope as well. Results: results indicated that: serum levels of the creatinine,IL-6 and BUN of treated rats showeda highly significantincreased compared to control animals, whereas serum magnesium showedhighly significantdecreased.Magnesiumsupplementationreverse these chages. In conclusion:Our study demonstrated that cisplatin induced andomized in the kidney function andMg supplementation ameliorates it. It is recommendedto do further investigations to determine therole of magnesium in cisplatin induced nephrotoxicity.
\end{abstract}

Keywords Keywords:Cisplatin, Magnesium, Nephrotoxicity, Chemotherapy.

\section{Introduction}

isplatin(cis-diammine-dichloroplatinum II) (CP) has been considered one of the most effective chemotherapeutic agents, used for treatment of a variety of human solid tumors. Activity has been proved against a variety of tumors, particularly of head and neck, esophageal, ovarian, testicular, bladder and lung cancers (Baek et al.,2003).

Such effective anticancer activity is associated with numerous toxicities at therapeutic doses as ototoxicity, gastrotoxicity, myelosuppressionand allergic reactions, but the main dose-limiting toxicity is nephrotoxicity (Hartmann and Lipp,2003; Milleret al., 2010). About 25\% to 35\% of patients develop evidence of nephrotoxicity following a single dose of cisplatin (Lee et al., 2009).
The exact mechanism of nephrotoxicity induced by cisplatin remains incompletely understood (Pabla and Dong, 2008). The pathophysiology of cisplatin-induced renal toxicityi ncluds four major mechanisms: (1) proximal tubular injury, (2) oxidative stress, (3) inflammation, (4) vascular injury. Proximal tubular injury involves several different mechanisms like mitochondrial dysfunction (Sugiyama et al.,1989),DNA damage (Leibbrandt et al., 1995),dysregulation of cell-cycle proteins ( Megyesi et al., 1998),activation of the mitogen-activated protein kinase (MAPK) signaling pathways ( Jo et al., 2005), direct toxicity to renal tubular epithelial cells (Ciarimboli et al., 2005),andapoptosis (Wei et al., 2007and Yang et al.,2008). 
Unbound cisplatin in the plasma is freely filtered by the glomerulidue to low molecular weight and uncharged character. Most of the cisplatin is trapped within the renal cortex (Safirstein et al., 1984; Launay-Vacher,et al., 2008).

kidney contributes to its nephrotoxicity (Kuhlmann et al., 1997; Kodama et al.,2014).

role in supporting health and life. Also it isinvolved in over 600 enzymatic reactions including energy metabolism and protein synthesis (de Baaij et al., 2015).

Additionally, magnesium acts as a cofactor for more than 300 enzymes in the body, including binding to ATP for kinase reactions, and affects permeability of excitable membranes and neuromuscular transmission (Benson, 2003) as well as nervous tissue electrical potential (Long and Romani, 2014).

Furthermore, magnesium is considered crucial for controlling extra cellular fluid volume, $\mathrm{Na}^{+} / \mathrm{K}^{+}$ATPase, cellular uptake of solutes, driving force for secondary active transport, and neuromuscular transmission (Benson, 2003).

Magnesium deficiency, characterized by increased inflammation and oxidative stress (Malpuech-Brugereet al., 2000)which results from an imbalance between $\mathrm{Mg}$ intake, absorption, and renal losses as well as increased metabolic demands (Mazur et al., 2007\&Nielsen, 2010).

The synergistic effects of $\mathrm{CP}$ and $\mathrm{Mg}$ deficiency are believed to contribute to renaldysfunction (Landon et al., 2013).

Precisely how Mg deficiency promotes CPinduced kidney injury is not known, and little has been done to prevent it.

The aim of this study was to evaluate the potential impact of magnesium supplementation onnephrotoxicity induced by cisplatin treatment in adult male albino rats.

\section{Materials and Methods}

\section{Ethical Consideration of Study}

The experimental procedures and the use of laboratory animal were approved by the Animal Research Committee in Zagazig University. Painless procedures were conducted. Animal housing and handling were ethically considered.

\section{Animals}

In this study 32 male Sprague-Dawley albino mature rats, weighing 200-220 g, were used. Animals were fed ad libitum and housed in pairs in steel cages, having a temperature-controlled environment (22 \pm $2^{\circ} \mathrm{C}$ ) with $12 \mathrm{~h} \mathrm{light/dark} \mathrm{cycles.}$

To abolish gender difference in this study, male rats were used as estrogen itself promotes nephrotoxicity induced by CP(Nematbakhshet al., 2012; Pezeshki et al., 2012).
The concentration of cisplatin in the proximal tubular cells is 5 times higher than the serum concentration and thus such an accumulation in

Magnesium is an essential ion to the human body, playsan important

\section{Experimental Protocol}

The experimental animals were randomly divided into four equal groups. Group I served as (Control group).GroupII (magnesium treated group) received single (i.p.) injection of magnesium sulphate $(90 \mathrm{mg} / \mathrm{kg})$, Groups III(Cisplatin treatedgroup) receivedsingle (i.p.) injection of $5 \mathrm{mg} / \mathrm{kg}$ body weight of cisplatinandGroup IV (Cisplatin andmagnesium treated group) received single (i.p.) injection of $90 \mathrm{mg} / \mathrm{kg}$ magnesium sulphate and $5 \mathrm{mg}$ of andomize The dosage of cisplatin was decided according to the previous work of Ikeguchiet al. (2000). They evaluated the toxicity of cisplatini.p. chemotherapy in rats. The toxicity of cisplatin was analyzed in tumor-free Donryu rats. Seven rats per group were given an i.p. injection of various doses of cisplatin $(7,8,9,10$ or $11 \mathrm{mg} / \mathrm{kg}$ ) with laparotomy under chloroform anesthesia. The volume of cisplatin solution administered was adjusted with physiological saline to $100 \mathrm{ml} / \mathrm{kg}$ body weight. The rats were observed for 14 days after administration of cisplatin, and the day of death was recorded. The $50 \%$ lethal dose (LD50) of cisplatin was calculated by the graphic approximation method (Finney, 1952). The calculated LD50 was $10 \mathrm{mg} / \mathrm{kg}$ of cisplatin. They used half of the LD50 concentration of cisplatin (5 $\mathrm{mg} / \mathrm{kg}$ ) in their experiments, and the volume of solutionadministered was adjusted to $100 \mathrm{ml} / \mathrm{kg}$ body weight (cisplatin, $50 \mathrm{mg} / \mathrm{ml}$ )

Other studies of Parlakpinaret al. (2002); Do Amaral et al. (2008); Lee et al. (2009); Choi et al. (2009) support the single dosage of cisplatin $(5 \mathrm{mg} / \mathrm{kg})$ proven to causenephrotoxicity.

Also duration of drug-treatment was decided according to the previous study of Han et al., (2008), who revealed that in the rat model , Mg depletion as a side effect of CP may occur 2 weeks after CP administration. And that, alteration in serum creatinine may lag several days behind actual renal injury.

The dosage of magnesium was decided according to the previous work of Mochizuki et al. (1998). They evaluated the toxicity of a single dose of magnesium sulfatein rats. They administered Magnesium sulfate once at dose levels of $90,130,200,300$ and 450 $\mathrm{mg} / \mathrm{kg}$ to rats of both sexes. Deaths occurred in the $200 \mathrm{mg} / \mathrm{kg}$ and above groups in both sexes. The LD50 values were $206 \mathrm{mg} / \mathrm{kg}$ for males and 174 $\mathrm{mg} / \mathrm{kg}$ for females. In the surviving animals, in the $130 \mathrm{mg} / \mathrm{kg}$ and above groups, tonic convulsions, abnormal gait and tachypnea were seen. 
Rats' body weight were recorded daily, At the end of experiment (14 days),blood samples were obtained from each rat then all animals were scarified under light ether anathesia,serum was collected and stored at $-20{ }^{\circ} \mathrm{C}$ until measurement. The kidneys were removed and weighed then stained for histopathological studies.

\section{Biochemical parameters}

\section{Blood urea nitrogen, Serum creatinine and Serum magnesium level}

Blood urea nitrogen was determined using "UreaseGLDH": enzymatic UV test ,according to Thomas method (Thomas, 1998) using DiaSys reagent kits.

Serum creatinine was determined by using kinetic test without deproteinization according to Newman and Price method (Newman and Price ,1999) using DiaSys reagent kits.

Serum magnesium (Mg) level was determined using quantitative kits according to (Simonsen et al., 1947)

\section{Measurement of serum IL-6}

Serum IL-6 estimated by ELISA technique using kits supplied by Cytimmune sciences INC,8075 Green mead Drive.College park Mary Land 20740.

\section{Tissue parameters}

Kidneys were immediately dissected out and grossly inspected to assess any gross abnormalities then washed with cold normal saline and used forhistopathological study.

\section{Light microscope examination}

The kidneys were fixed in $10 \%$ formalin solution. After fixation, tissues were embedded in paraffin blocks and processed for $5 \mathrm{u}$. thickness sections. These sections were stained byHematoxyin and Eosin stains (Horobin and Bancroft, 1998) and then examined by light microscope.

\section{Statistical analysis}

Data were analyzed by Statistical Package of Social Science (SPSS), software version 22.0 (SPSS Inc., 2013).

\section{Results}

No rats died during or after the injections.
As regard body weight and kidney weight $A t$ the beginning of the experiment, the initial animals' weight was recorded with non-significant differences between the different groups(table 1).

After the experiment, there was significant decrease in body weight and increase in kidney weight in CP treated group when compared with control group. Magnesium significantly prevented, but did not normalize, cisplatin-induced weight loss in magnesium and CP treated group.While $\mathrm{Mg}$ alone had no significant effect(Table 1).

\section{As regard blood urea nitrogen and serum creatinine:}

A highly significant increase in BUN and serum Creatinine levels were observed in cisplatin treated group when compared with that in control group. $\mathrm{Mg}$ supplementation at the dosages of $90 \mathrm{mg} / \mathrm{kg}$ could significantly reduce the increase in BUN and serum Creatinine levels compared with that in CP treated group). While $\mathrm{Mg}$ at the dose of $90 \mathrm{mg} / \mathrm{kg}$ alone had no observable effect on levels of both(Table 2).

\section{As regard serum magnesium level}

There was significant decrease in serum $\mathrm{Mg}$ level in cisplatin treated rats when compared with control group(Table 2)

\section{As regardinflammatory marker (IL6)}

Ahigh significant increase in IL-6 was observed in cisplatin treated group when compared with control group. Mg administration modify the inflammatory markers,as there was decrease in IL-6 in cisplatin and $\mathrm{Mg}$ treated group when compared with cisplatin treated group (Table 2).

\section{As regard histopathological changes}

Stained kidney section for the control rats and $\mathrm{Mg}$ alone groups were normal when were examined under light microscope (Figs. 1, 2).

Histological abnormalities in kidney tissue were observed in CP treated groupasatrophied glomeruli, necrosis in renal tubule, dilated proximal convoluted tubule with slogged epithelium and hemorrhage.(Figs. 3,4,5).

While in $\mathrm{Mg}$ and $\mathrm{CP}$ treated group markedly attenuation in the histopathological changes were seen (Fig.6). 
Table (1): ANOVA one was statistical analysis, comparisons between different rats groups regarding initial, final body weight (gm) and kindney weight (gm).Each group of 8 rats.

\begin{tabular}{|c|c|c|c|c|c|c|c|c|}
\hline Groups & $\begin{array}{c}\text { Controlgoup } \\
\text { Mean } \pm \text { SD }\end{array}$ & $\begin{array}{l}\text { Mg group } \\
\text { Mean } \pm \text { SD }\end{array}$ & $\begin{array}{l}\text { CP group } \\
\text { Mean } \pm \text { SD }\end{array}$ & $\begin{array}{c}\text { Mg+CP } \\
\text { group } \\
\text { Mean } \pm S D\end{array}$ & $\mathbf{F}$ & \multicolumn{3}{|c|}{ LSD } \\
\hline $\begin{array}{l}\text { Initial Body } \\
\text { weight (gm) }\end{array}$ & $210 \pm 5$ & $211 \pm 6$ & $210 \pm 3$ & $211 \pm 2$ & 0.144 & & & \\
\hline \multirow[t]{3}{*}{$\begin{array}{l}\text { Final Body } \\
\text { weight (gm) }\end{array}$} & \multirow[t]{3}{*}{$222 \pm 6$} & \multirow[t]{3}{*}{$220 \pm 3$} & \multirow[t]{3}{*}{$198 \pm 5$} & \multirow[t]{3}{*}{$218 \pm 3$} & \multirow[t]{3}{*}{50.093} & $\begin{array}{l}0.77 \\
\text { N.S } \\
\mathrm{a} \\
\end{array}$ & $\begin{array}{c}<0.0001^{* *} \\
\mathrm{a}\end{array}$ & $\begin{array}{c}0.2 \\
\text { N.S } \\
\mathrm{a} \\
\end{array}$ \\
\hline & & & & & & \multicolumn{2}{|c|}{$<0.0001^{* *} \quad \mathrm{~b}$} & $\begin{array}{c}0.77 \\
\text { N.S } \\
\mathrm{b} \\
\end{array}$ \\
\hline & & & & & & \multicolumn{3}{|c|}{$<0.0001^{* *} \mathrm{C}$} \\
\hline \multirow[t]{3}{*}{$\begin{array}{l}\text { kidney weight } \\
\text { (gm) }\end{array}$} & \multirow[t]{3}{*}{$0.54 \pm 0.05$} & \multirow[t]{3}{*}{$0.54 \pm 0.03$} & \multirow[t]{3}{*}{$0.59 \pm 0.02$} & \multirow[t]{3}{*}{$0.56 \pm 0.05$} & \multirow[t]{3}{*}{2.836} & $\begin{array}{c}0.99 \\
\text { N.S } \\
\text { a } \\
\end{array}$ & $\begin{array}{c}0.037 \\
\mathrm{a}\end{array}$ & $\begin{array}{l}0.67 \\
\text { N.S a }\end{array}$ \\
\hline & & & & & & \multicolumn{2}{|c|}{$0.037^{*} \quad \mathrm{~b}$} & $\begin{array}{l}0.67 \\
\text { N.S } \\
\text { b }\end{array}$ \\
\hline & & & & & & & 0.34 N.S & \\
\hline
\end{tabular}

SD: Standard Deviation, *: significant $(p<0.05)$, **: highly significant $(p<0.01), a=v e r s u s$ control, $b=v e r s u s ~ M g$ $C=$ versus $C S$ 
Table (2): ANOVA one was statistical analysis, comparisons between different rats groups regarding serum level of BUN (mg/dl), creatinine (mg/dl), Mg 1 (mg/dl ) and IL-6 (pg/Ml).Each group of 8 rats.

\begin{tabular}{|c|c|c|c|c|c|c|c|c|}
\hline $\begin{array}{l}\text { Groups } \\
\text { Parameter }\end{array}$ & $\begin{array}{l}\text { Control } \\
\text { Mean } \pm \text { SD }\end{array}$ & $\begin{array}{c}\text { Mg } \\
\text { Mean } \pm \text { SD }\end{array}$ & $\begin{array}{c}\text { CS } \\
\text { Mean } \pm S D\end{array}$ & $\begin{array}{c}\text { Mg+CS } \\
\text { Mean } \pm \text { SD }\end{array}$ & $\mathbf{F}$ & \multicolumn{3}{|c|}{ LSD } \\
\hline \multirow[t]{3}{*}{$\begin{array}{l}\text { BUN } \\
\text { ( mg/dl) }\end{array}$} & \multirow[t]{3}{*}{$50.7 \pm 9.14$} & \multirow[t]{3}{*}{$45.2 \pm 4.14$} & \multirow[t]{3}{*}{$98.1 \pm 19.11$} & \multirow[t]{3}{*}{$53.4 \pm 8.95$} & \multirow[t]{3}{*}{26.942} & $\begin{array}{c}0.72 \\
\text { N.S } \\
\mathrm{a}\end{array}$ & $\begin{array}{c}<0.0001^{* *} \\
\mathrm{a}\end{array}$ & $\begin{array}{c}0.95 \text { N.S } \\
\text { a }\end{array}$ \\
\hline & & & & & & \multicolumn{2}{|c|}{$<0.0001^{* *} \quad \mathrm{~b}$} & $\begin{array}{c}0.17 \text { N.S } \\
\mathrm{b}\end{array}$ \\
\hline & & & & & & \multicolumn{3}{|c|}{$<0.0001^{* *} \quad \mathrm{C}$} \\
\hline \multirow[t]{3}{*}{$\begin{array}{l}\text { Creatinen } \\
\text { (mg/dl) }\end{array}$} & \multirow[t]{3}{*}{$0.33 \pm 0.04$} & \multirow[t]{3}{*}{$0.27 \pm 0.04$} & \multirow[t]{3}{*}{$0.50 \pm 0.07$} & \multirow[t]{3}{*}{$0.44 \pm 0.04$} & \multirow[t]{3}{*}{35.739} & $\begin{array}{c}0.17 \\
\text { N.S } \\
\text { a }\end{array}$ & $\begin{array}{c}<0.0001^{* *} \\
\mathrm{a}\end{array}$ & $\begin{array}{l}0.0024 \\
* * \quad \mathrm{a}\end{array}$ \\
\hline & & & & & & \multicolumn{2}{|c|}{$<0.0001^{* *} \quad \mathrm{~b}$} & $\begin{array}{c}<0.0001 \\
* * \quad \mathrm{~b}\end{array}$ \\
\hline & & & & & & \multicolumn{3}{|c|}{0.17 N.S C } \\
\hline \multirow[t]{3}{*}{$\begin{array}{l}\text { Mg } \\
(\mathrm{mg} / \mathrm{dl})\end{array}$} & \multirow[t]{3}{*}{$4.53 \pm 0.1$} & \multirow[t]{3}{*}{$4.54 \pm 0.1$} & \multirow[t]{3}{*}{$3.33 \pm 0.1$} & \multirow[t]{3}{*}{$4.5 \pm 0.2$} & \multirow[t]{3}{*}{162.880} & $\begin{array}{c}0.99 \\
\text { N.S } \\
\mathrm{a}\end{array}$ & $\begin{array}{c}0.00022^{* *} \\
\mathrm{a}\end{array}$ & $\begin{array}{c}0.96 \text { N.S } \\
\text { a }\end{array}$ \\
\hline & & & & & & 0.00 & $9^{* *} \quad \mathrm{~b}$ & $\begin{array}{c}0.91 \text { N.S } \\
\mathrm{b}\end{array}$ \\
\hline & & & & & & \multicolumn{2}{|r|}{$<0.0001^{* *}$} & C \\
\hline \multirow[t]{3}{*}{$\begin{array}{l}\text { IL-6 } \\
\text { (pg/Ml) }\end{array}$} & \multirow[t]{3}{*}{$1.87 \pm 0.89$} & \multirow[t]{3}{*}{$1.88 \pm 0.80$} & \multirow[t]{3}{*}{$2.55 \pm 0.1$} & \multirow[t]{3}{*}{$1.9 \pm 0.33$} & \multirow[t]{3}{*}{2.296} & $\begin{array}{c}0.99 \\
\text { N.S } \\
\mathrm{a}\end{array}$ & $\begin{array}{c}0.08 \text { N.S } \\
\text { a }\end{array}$ & $\begin{array}{c}0.99 \text { N.S } \\
\text { a }\end{array}$ \\
\hline & & & & & & 0.09 & N.S & $\begin{array}{c}0.99 \text { N.S } \\
\text { b }\end{array}$ \\
\hline & & & & & & & 0.11 N.S & C \\
\hline
\end{tabular}

SD: Standard Deviation, *: significant $(p<0.05)$, **: highly significant $(p<0.01), a=v e r s u s$ control, $b=v e r s u s ~ M g$ $c=$ versus $C S$ 


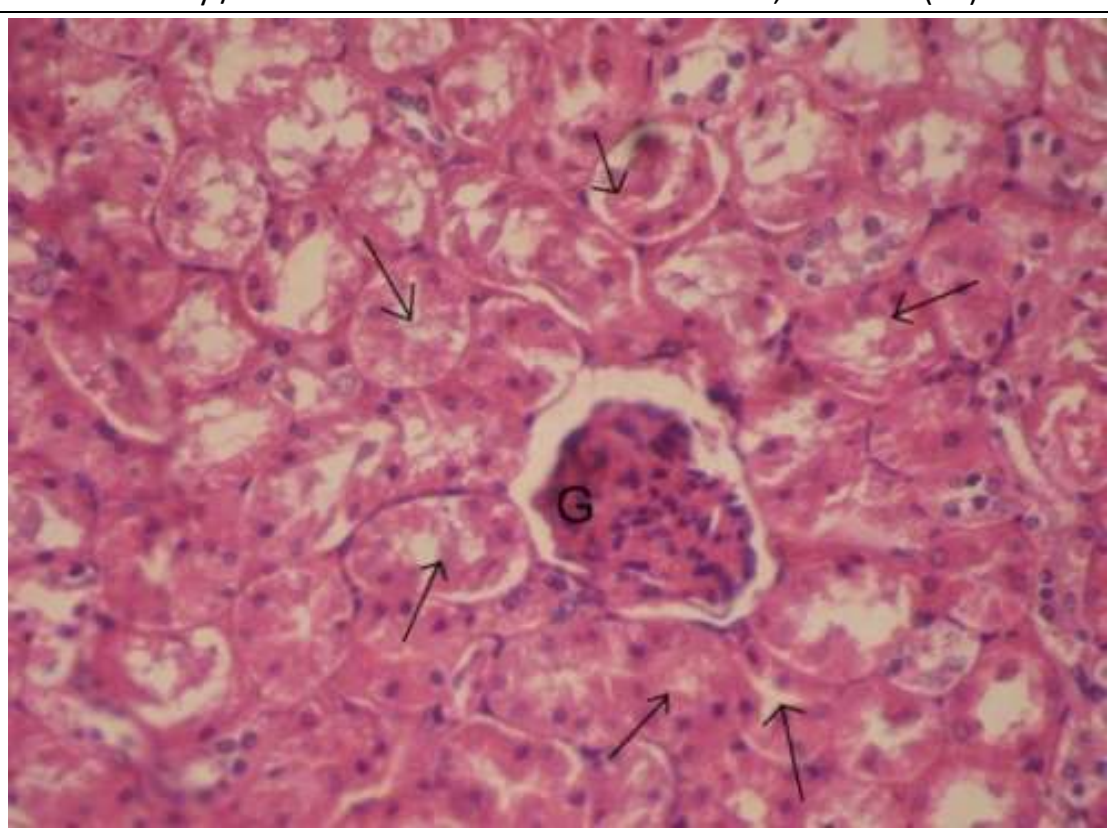

Fig.(1):A photomicrograph of kidney section of a control rat group showing normal glomeruli(G) and normal renal tubule(arrow). (H \& E X 40)

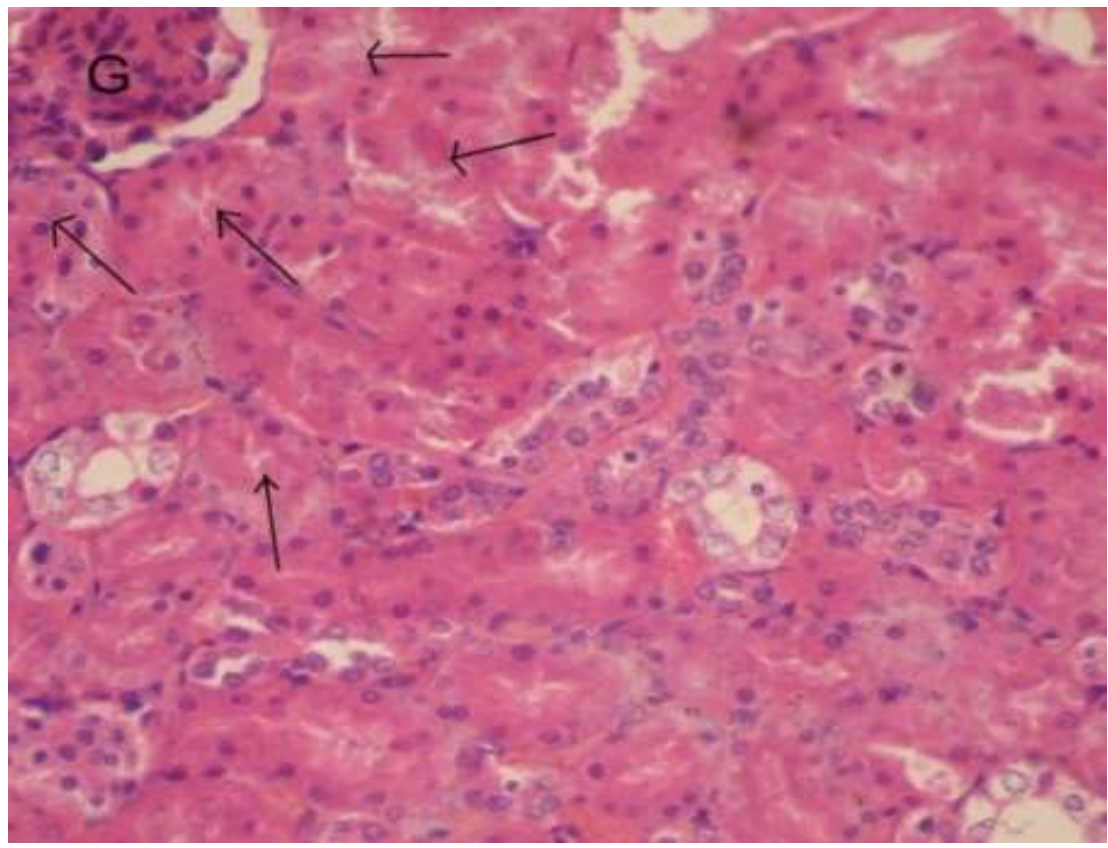

Fig.(2):A photomicrograph of kidney section of Magnesiumtreated group showing normal glomeruli(G) and normal renal tubule(arrow). (H \& E X 40) 


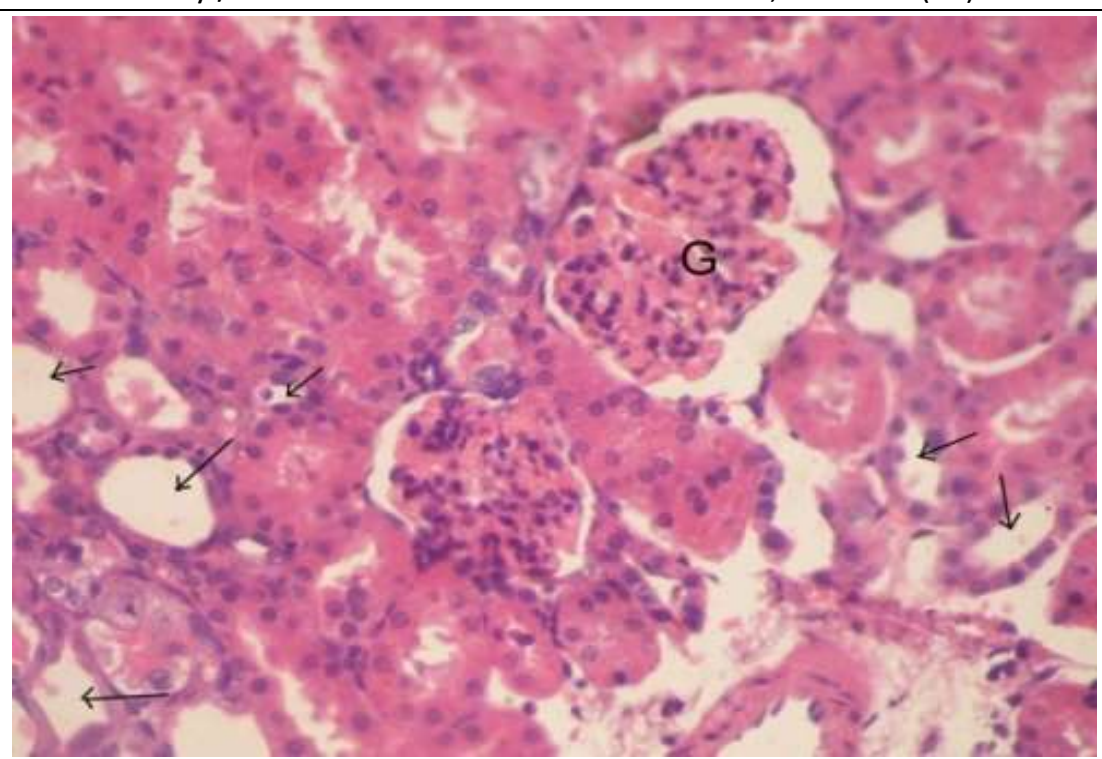

Fig.(3):A photomicrograph of kidney section of a cisplatintreatrd group showing atrophied glomerulus $(G)$ and acute necrosisin renal tubule(arrow). (H \& E X 40)

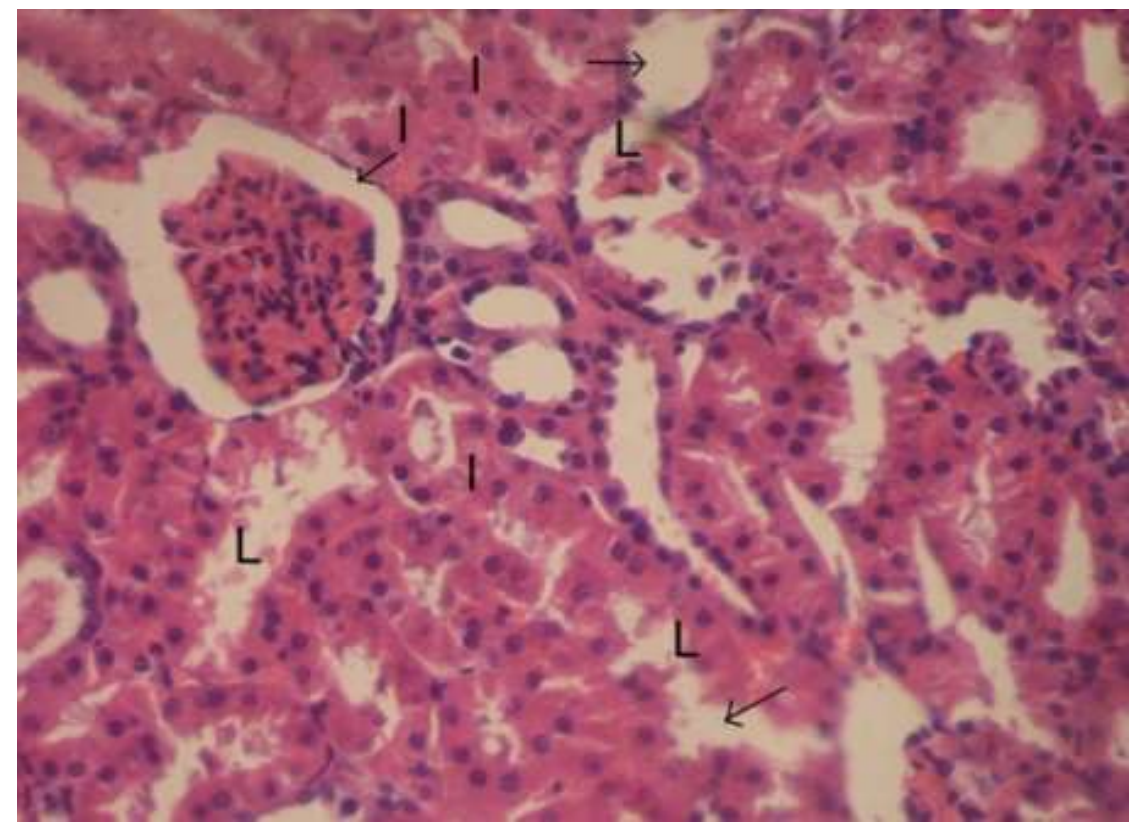

Fig.(4): A photomicrograph of kidneysection of a cisplatintreatrd group showing the dilated Proximal Convoluted Tubule with slogged of epithelium (arrow). Note the tubular lumen (L) filled with cellular debris and elevated tissue in interstitium(I) indicative of necrotic cell. (H \& E X 40) 


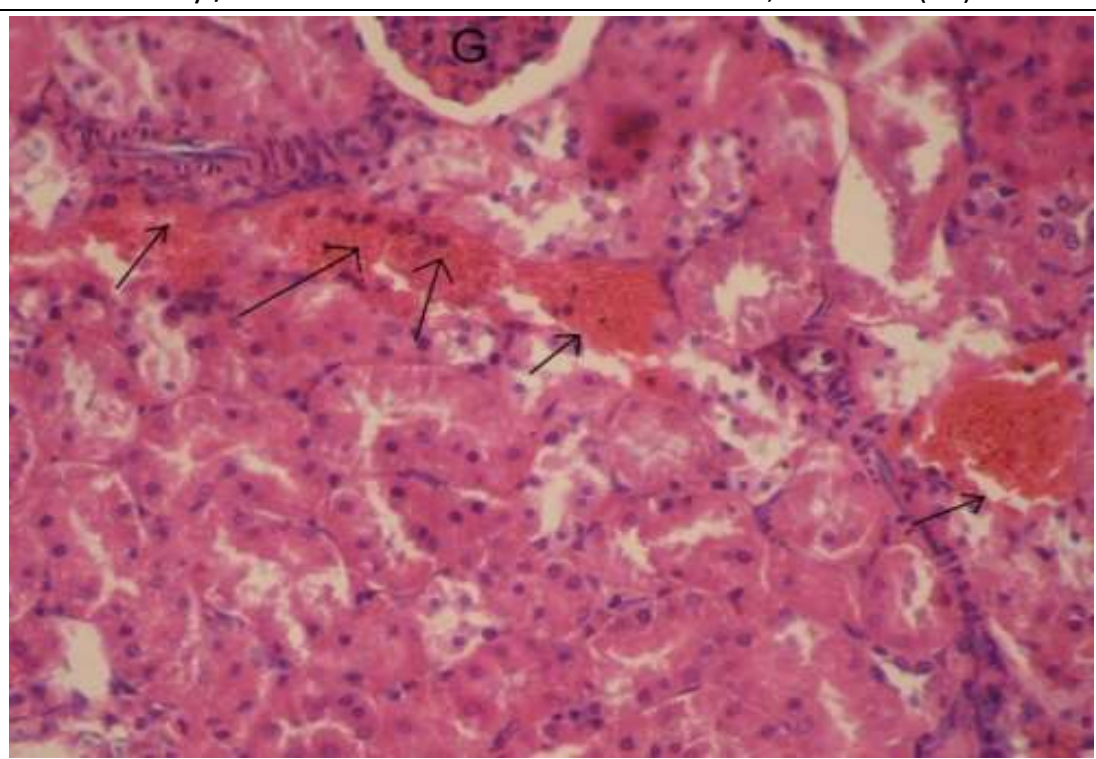

Fig.(5):A photomicrograph of kidney section of a cisplatintreatrd group showing area of hemorrhage.(H \& E X 40)

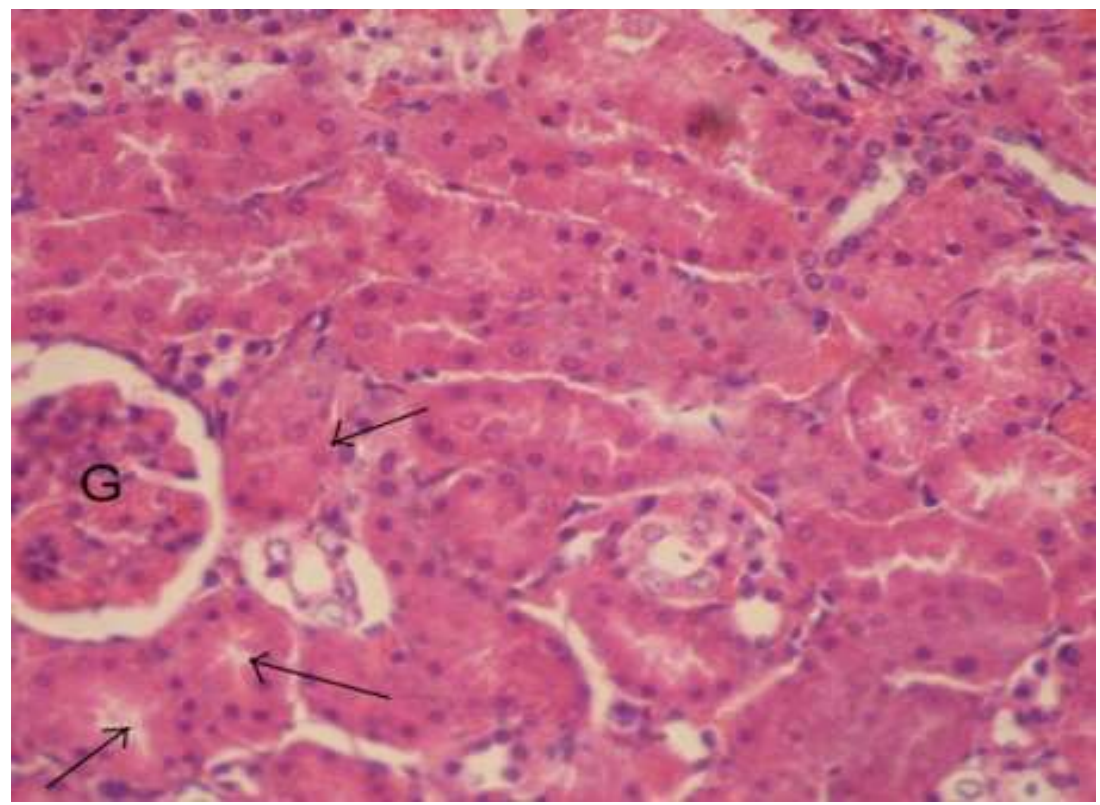

Fig.(6): A photomicrograph of kidney section of a cisplatin andMagnesiumtreatrd group showingshowingnormal glomeruli(G) and normal renal tubule(arrow).(H \& E X 40)

\section{Discussion}

Cisplatin is one of the most achieved successes in the war on cancer. Since the accidental discovery over four decades ago, it has been widely used as chemotherapeutic (Wang andLippard,2005).

The side effects of cisplatinis considered as major limiting factor in its use, which include neurotoxicity, ototoxicity, nausea, vomiting, and nephrotoxicity (Pasettoet al., 2006)

Renal toxicity is a well-known adverse effect of cisplatin treatment. Despite intensive prophylactic measures, renal toxicity still affects a large number of patients treated with it (Daugaardet al., 1988).
Few days after initiating treatment, about onethird of cisplatin-treated patients exhibited reduced glomerular filtration rates (Pablaand Dong, 2008).

After a single dose of cisplatin50 $100 \mathrm{mg} / \mathrm{m} 2$ ), approximately one-third of the patients develop nephrotoxicity (Lebwohl and Canetta, 1998;Shiraishi et al., 2000)

Increased oxidative stress, inflammation, and apoptosis are considered mechanisms of Cpinduced nephrotoxicity (Pabla and Dong, 2008;Miller et al., 2010; Sanchez-Gonzalez et al., 2011).

Nephrotoxicity is manifested by increased blood urea nitrogen (BUN) and creatinine (Cr), as well 
many histological aspects of renal tissue.CP-induced nephrotoxicity disturbs tubular reabsorption of $\mathrm{Mg}$, leading to $\mathrm{Mg}$ depletion whichenhances nephrotoxicity(Lajer et al., 2005a;Lajer etal., 2005b).The prevention of CP-induced nephrotoxicity in patients remains a great challenge, because there are no specific nephron protective therapies.

The synergistic effects of CP and $\mathrm{Mg}$ deficiency are believed to contribute to renal dysfunction (Lajer et al., 2005a). Precisely how Mg deficiency promotes CP-induced kidney injury is not known, and little has been done to prevent it (Miller et al., 2010), for that the main objective of this study was to determine the role of $\mathrm{Mg}$ supplementation in CPinduced nephrotoxicity.

In the present study, Cisplatin administration in rats produced a significant decrease in body weight and increase in kidney weight, this is in line with(Ranaet al., 2016), who found similar results. They explained that,the decreased body weight observed may result from the increased catabolism and decreased food intake. The increase in kidney weight resulted from the edema due to drug induced tubular necrosis.

Also, another study of Ahangarpour et al. (2014),attributed that to the injured renal tubules, with the subsequent loss of the tubular cells to reabsorb water leading to dehydration and loss of body weight.

In contrast of a single dose of cisplatin administration to rat did not induce any significant changes in both body and kidney weights (Habib et al., 2015). This was probably due to short time of study (3 days).

According toDe Francisco and Rodríguez(2013) there is a strong relationship between renal function and magnesium level. As study of 550 type2DM patients with no known kidney disease indicated that lower magnesium levels correlated with progressive deterioration of renal function.

In the present study, There was significant decrease in Mg level in cisplatin treated group, this is in agreement with LajerandDaugaard (1999) who reported that, Cisplatin treatment causes magnesium deficiency in about $90 \%$ of patients who did not receive prophylactic magnesium supplementation due to renal tubular magnesium wasting.

The results of a study made by Bodnar et al.(2008)indicated that prophylactic magnesium supplementation, in addition to the prevention side effects that result from magnesium deficiency, can decrease the severity of cisplatin-induced renal damage without interfering with the its anticancer effect. In fact, among cisplatin-treated cancer patients, those given magnesium had nonesignificantly slower disease progression and longer survival times, when compared with patients given a placebo.

Human organic cation transporter 2 (OCT2) is responsible for the uptake of organic cations across the basolateral membrane in kidneys(Fujita et al., 2006).

Moreover, OCT2 is Mg-dependent and hypomagnesemia causes upregulation of OCT2, which increases the accumulation of CP in the kidney( Filipskiet al., 2009; Yokooet al., 2009).
Cisplatin induces hypomagnesemia through its renal toxicity by a direct injury to mechanisms of magnesium reabsorption in the ascending limb of the loop of Henle as well as the distal tubule(Lajer and Daugaard, 1999).

Possible symptoms of hypomagnesemia can be impossible to distinguish from symptoms related to the underlying disease or the treatment with chemotherapy. Existing studies on how to supplement magnesium during treatment with cisplatin have focused mainly on the effect on serum magnesium levels and erythrocyte magnesium concentrations but both parameters are poor indicators of body magnesium stores( LajerandDaugaard, 1999;Lajer et al., 2005b)

As long as the relationship between hypomagnesemia and possible complications thereof remains poorly elucidated, it seems reasonable to try to avoid hypomagnesemia. The best results seem to be provided by adding magnesium to the pre- and posthydration fluids( LajerandDaugaard, 1999; Lajer et al., 2005b).

In our study, biochemical markers of serum confirmed that,cisplatin in a single dose of $5 \mathrm{mg} / \mathrm{kg}$ produced significant nephrotoxicity as indicated by a significant increase in BUN and serum creatinine levels. Thisis in agreement withBokemeyer et al. (1996) who,reported that cisplatin $(5 \mathrm{mg} / \mathrm{kg}$ ) can cause an elevation in BUN levels at least 3 days after cisplatin has been administered.Magnesium supplementation of cisplatin treated rats attenuated the cisplatin-induced nephrotoxicity as shown in decrease in the serum levels of BUN and serum creatinine .

Our results are in parallel with the outcomes of the study of Willox et al. (1986)who, revealed that supplementation with $16 \mathrm{mEq} \mathrm{Mg}$ was beneficial in reducing renal tubular damage in patients with testicular cancer receiving cisplatin, while Bodnar et al.(2008) demonstrated that $40 \mathrm{mEq} \mathrm{Mg}$ supplementation had nephron protective effects during chemotherapy with cisplatin in patients with epithelial ovarian cancer.

Muraki et al. (2012) showed that hydration with $8 \mathrm{mEq} \mathrm{Mg}$ and mannitol without furosemide prevents the nephrotoxicity induced by cisplatin.

Muraki etal.(2013)also showed that $20 \mathrm{mEq} \mathrm{Mg}$ supplementation may be beneficial in preventing cisplatin-induced nephrotoxicity in patients with esophageal or hypopharyngeal cancer.

Yoshida et al.(2014)reported that $8 \mathrm{mEq} \mathrm{Mg}$ preloading before cisplatin administration significantly reduced cisplatin-induced nephrotoxicity in 496 patients with thoracic malignancies .

$\mathrm{Mg}$ supplementation is being considered an option for cisplatin-based chemotherapy. Prospective studies since 2007 have examined the use of lowvolume hydration in combination with $\mathrm{Mg}$ supplementation. Studies showed that low-volume hydration with $16 \mathrm{mEq} \mathrm{Mg}$ supplementation in cisplatin-based chemotherapy led to no increase in creatinine in only $35.3 \%$ of patients (Yoshida et al.,2007). 
According to Hotta et al.(2013) low-volume hydration (2,500 ml) with $4 \mathrm{mEq}$ Mg supplementation before and after cisplatin administration was associated with slightly worse renal toxicity during all cycles of chemotherapy, without significance .

Horinouchi et al. (2013)examined the safety of low-volume hydration $(1,550-2,050 \mathrm{ml})$ with $8 \mathrm{mEq} \mathrm{Mg}$ supplementation; however, renal function during all courses of cisplatin administration was slightly worse.

There was strong evidence that Cisplatininduced renal injury was caused by the accumulated exposure of the drug in the tubules(Kannan and Jain,2000) in which the glomerular filtration rate was reduced and followed by an increase of BUN and serum creatinine levels(Edelstein, 2008). Other laboratories had established well proven rat models, in which Cisplatin was administrated with a single intraperitoneally (i.p) injection at 5 10 $\mathrm{mg} / \mathrm{kg}$ (Ravi et al., 1995).

In the current study, such animals were given one dosage of Cisplatin $(5 \mathrm{mg} / \mathrm{kg}$ ) and renal function parameters, such as BUN and serum creatinine levels, as well as morphology characteristics, were observed. There were obvious pathological changes 5 days after injection, which were all attenuated by $\mathrm{Mg}$ cotreatment. Thus, magnesium might have potential protective effect against the renal damage induced by Cisplatin. The rational of obtaining biochemical parametes is due to the fact that, alterations in serum creatinine may lag several days behind actual changes in GFR(Moran and Myers, 1985;Star,1998).

Regarding inflammatory markers,numerous studies have connected Mg deficiency with enhanced inflammation in the intestines, heart (Chmielinska et al.,2005; Scanlan et al., 2007), and lungs (Nasulewicz et al.,2004).

Adequate Mg balance has been reported to reduce the risk of inflammation(Dibaba and Xun , 2014).

Magnesium deficiency induced inflammation, can lead to increased TNF- $\alpha$, IL-6, and IL-1 production in rats (Weglicki et al., 1992; Malpuech-Brugère et al., 1999; Shogi et al., 2002), supporting a link between magnesium and, inflammation, which were consistent with our results.

In contrast, previous studies in humans have not found a correlation between magnesium levels and secreted cytokines (Mezad et al., 2002; Nowacki W et al., 2009). These studies were limited by small samples sizes, measured serum cytokine levels in nonrandomized patients, or exposed diluted blood to a high LPS concentration.

Also, Habib et al. (2015)found thatCP (12 $\mathrm{mg} / \mathrm{kg}$ ) did not increase renal cytokines at $48 \mathrm{~h}$. However, when CIS was combined with $\mathrm{Mg}$ deficiency, renal IL-6 and IL-1 $\beta$ protein levels were significantly elevated

Experimental Mg deficiency in rats induces a clinical inflammatory syndrome characterized by leukocyte and macrophage activation, synthesis of inflammatory cytokines and acute phase proteins, extensive production of free radicals.An increase in extracellular Mg concentration decreases inflammatory effects (Rayssiguier and Mazur, 2005)

In humans, an inverse association between markers of chronic inflammation and $\mathrm{Mg}$ intake has been reported on serum levels (Rodriguez-Moran andGuerrero-Romero, 2004; Song et al., 2005; Bo et al., 2006; Song Y et al., 2007).

The inverse association between $\mathrm{Mg}$ and Creactive protein suggested that $\mathrm{Mg}$ deficiency might be involved in the development of low chronic inflammatory syndrome, which can modulate metabolic disorders; Mg supplementation has been shown to reduce CRP blood levels in patients with heart failure. Even if, in epidemiological studies,the association between $\mathrm{Mg}$ and inflammatorymarkers is not always evidenced (Bo and Pisu , 2008).

Several studies have been performed to assess the activation of proinflammatory cells in $\mathrm{Mg}$ deficiency. Mg-deficient rats are more sensitive to immune stress, as measured by TNF $\alpha$ response, following an endotoxin challenge. Increasing extracellular $\mathrm{Mg}$ concentration in vivo or in vitro decreased the inflammatory response as shown by chemiluminescence studies or cytokine production (Rayssiguier et al., 2006; Mazur et al., 2007).

Long-term $\mathrm{Mg}$ deficiency also results in inflammation and oxidative stress (Blache et al., 2006).

Many studies have suggested that magnesium sulfate (MgSO4) solution has anti-inflammatory properties in many conditions(Dabbagh et al., 2009;Mirkheshti et al., 2012; James, 2009;Singh et al., 2008).

Also, Sugimoto et al. (2012) stated that, MgSO4 is safe and well tolerated, and their findings suggest that magnesium could be used therapeutically as a broad-spectrum anti-inflammatory agent. In addition, it has also been demonstrated in a number of studies that magnesium can modulate cellular events involved in inflammationwhile activation of leukocyte and macrophage and the release of inflammatory cytokines are the characteristic features of this inflammatory syndrome (Mazur, et al., 2007; Rayssiguier et al .,2010). Among the main proposed mechanisms for the anti-inflammatory effects of MgSO4, the 'phosphoinositide 3-kinase/Akt pathway' is one of the most important ones. Meanwhile, another main mechanism seems to be the suppressing role of magnesium throughout the inflammatory process by the 'activation of N-methyl-d-aspartate (NMDA) receptors. Since, magnesium is a natural antagonist of calcium ion and $\mathrm{MgSO} 4$, which acts through inhibition of 'N-methyl-D-aspartate dependent cellular pathways'(James, 2009; Rayssiguier et al., 2010).

On the other hand, it has been demonstrated that decreased plasma levels of magnesium can activate inflammatory neuromediators via the activation of 'neuroendocrinological pathways (Iezhitsa et al., 2011).

The histopathological evidences further confirmed our biochemical findings. Besides significantly decreasing the levels of creatinine and BUN, Mg supplementationwith cisplatin ameliorated its certain nephrotoxic effects in the histopathological 
examination, such as tubular degeneration, nuclear condensation, apoptosis and inflammation. Cisplatininduced extensive tubular degeneration and the other histological alterations were also revealed in the previous studies( Davis et al., 2001;Sahu et al., 2011;Ozkol et al., 2012; Al-Kharusi et al., 2013).

Magnesiumsupplementation greatly attenuate histopathological damage present in cisplatin treated rats. Similar results were found in a study of(Malvika et al., 2015).

In contrast to that, a study of Soltani et al.(2013), they found no protective effect of magnesium supplementation on cisplatin induced histopathological damage of nephrotoxicity. Notably, they used oral preparation of magnesium in diabetic rats.

However, Ashrafi et al. (2012)concluded that $\mathrm{Mg}$ supplementation is not nephroprotective against CP-induced nephrotoxicity. Added to that, under some conditions, supplementation may promote kidney toxicity. This controversy of the effect of $\mathrm{Mg}$ supplementation on cisplatin induced nephrotoxicity might be due to different reasons; the use of different doses and routes of administration of $\mathrm{Mg}$ supplementation.

Also, the fact that $>90 \%$ of total body magnesium is intracellular, compartmentalized within organelles, bound to protein, or complexed to ATP (Romani,2007).

Extracellular ionized magnesium is readily measurable, but intracellular magnesium, which is not measured clinically and does not correlate with extracellular magnesium levels, is the biologically relevant form(Franz, 2004).

This limitation in our ability to accurately evaluate magnesium status has been a critical barrier to progress in understanding the prevalence and impact of magnesium deficiency (Shils,1999) therefore further studies are required to determine the exact role of magnesium in cisplatin induced nephrotoxicity.

\section{Refrances}

AhangarpourA,FardAA,GharibnaseriMKet al., (2014): Hydrogen sulfide ameliorates the kidney dysfunction and damage in cisplatin-induced nephrotoxicity in rat.Vet. Res. Forum., 5(2): 121-127.

Al-Kharusi N,Babiker HA,Al-Salam et al., (2013): Ellagic acid protects against cisplatin-induced nephrotoxicity in rats: a dose-dependent study. Eur. Rev. Med. Pharmacol. Sci., 17: 299-310.

AshrafiF, Haghshenas S,NematbakhshM et al., (2012): The Role of Magnesium Supplementation in Cisplatin-induced Nephrotoxicity in a Rat Model: No Nephroprotectant Effect. Int. J. Prev. Med., 3(9): 637-643.

Baek SM, Kwon CH, Kim JH et al., (2003): Differential roles of hydrogen peroxide and hydroxyl radical in cisplatin-induced cell death in renal proximal tubular epithelial cells. J. Lab. Clin. Med., 142: 178-186.

Benson R (2003):Metabolism and Nutrition: Second Edition. London, UK: Elsevier Health Sciences.
Blache D, Devaux S, Joubert O et al.,(2006): Longterm moderate magnesium-deficientdiet shows relationships between blood pressure, inflammation and oxidant stress defense in aging rats. Free Radic. Biol. Med., 41: 277-84.

Bo S,Durazzo M,GuidiS et al., (2006): Dietary magnesium and fiber intakes and inflammatory andmetabolic indicators in middle-aged subjects from a population-based cohort. Am. J. Clin. Nutr. , 84: 1062-9.

Bo Sand Pisu E (2008): Role of dietary magnesium in andomized lar disease prevention, insulin sensitivity and diabetes. Curr. Opin. Lipidol, 19: 50-6

Bodnar L,Wcislo G,Gasowska-BodnarA et al.,(2008): Renal protection with magnesium subcarbonate and magnesium sulphate in patients with epithelial ovarian cancer after cisplatin and paclitaxel chemotherapy: a andomized phase II study. Eur. J. Cancer.,44:2608-2614 .

Bokemeyer C,Fels LM,Dunn T et al., (1996):Silibinin protects against cisplatin-induced nephrotoxicity without compromising cisplatin or ifosfamide anti-tumour activity. Br. J. Cancer, 74:20362041.

Chmielinska JJ,Tejero-Taldo MI,Mak IT et al., (2005): Intestinal and cardiac inflammatory response shows enhanced endotoxin receptor (CD14) expression in magnesium deficiency. Mol. Cell Biochem., 278: 53-57.

Choi DE, Jeong Jyand Lim BJ(2009):Pretreatment with darbepoetin attenuates renal injury in a rat model of cisplatin-induced nephrotoxicity. Korean J. Intern. Med., 24: 238-246.

Ciarimboli G, Ludwig T, and Lang D(2005): "Cisplatin nephrotoxicity is critically mediated via the human organic cation transporter 2," The American Journal of Pathology, 167(6): 14771484.

Dabbagh A, Elyasi H,Razavi S.S et al., (2009): Intravenous magnesium sulfate for postoperative pain in patients undergoing lower limb orthopedic surgery. Acta Anaesthesiol. Scand.,53(8):1088-91 .

Daugaard G,Abildgaard U, Holstein-Rathlou NH et al.,(1988): Renal tubular function in patients treated with high-dose cisplatin. Clin. Pharmacol. Ther., 44:164-172 .

Davis CA,Nick Hsand AgarwalA(2001):Manganese superoxide dismutase attenuates cisplatininduced renal injury: importance of superoxide. J. Am. Soc. Nephrol., 12: 2683-2690.

De Baaij JH,Hoenderop JG,and Bindels RJ (2015): Magnesium in man: implications for health and disease. Physiol. Rev.,95(1):1-46 .

De Francisco AL and Rodríguez M (2013):Magnesium - its role in CKD. Nefrologia, 33:389-399.

DibabaDT and Xun P(2014): Dietary magnesium intake is inversely associated with serum Creactive protein levels: meta-analysis and systemic review.Eur. J. Clin. Nutr. ,68:510-516

Do Amaral CL, Francescato Hdand Coimbra TM (2008): Resveratrol attenuates cisplatin-induced 
nephrotoxicity in rats. Arch. Toxicol., 82: 363370

Edelstein CL (2008): Biomarkers of acute kidney injury. Adv. Chronic Kidney Dis., 15: 222-234.

Filipski KK,Mathijssenm RH,Mikkelsen TS, et al.(2009): Contribution of organic cation transporter 2 (OCT2) to cisplatin-induced nephrotoxicity. Clin. Pharmacol. Ther.;86:396402

Finney DJ (1952): Graphical estimation of relative potency from quantalresponses.J. Pharmacol. Exp. Therap., 104,440-444.

Franz KB (2004): A functional biological marker is needed for diagnosing magnesium deficiency. $\mathrm{J}$. Am. Coll. Nutr.,23:738S-741S .

Fujita T, Urban TJ,Leabman Mket al., (2006):Transport of drugs in the kidney by the human organic cationtransporter, OCT2 and its genetic variants. J. Pharm. Sci.,95:25-36.

Habib R, Begum S,Alam G et al., (2015): Transcription profile of genes affected in response to pathological changes in drug-induced rat model of acute kidney injury. Ren. Fail., Early Online: $1-7$.

HanWK,WaikarSS,Johnson A, et al.(2008): Urinary biomarkers in the early diagnosis of acute kidney injury. Kidney Int.,73(7): 863-869 .

Hartmann JT and Lipp HP (2003): Toxicity of platinum compounds. Expert Opin. Pharmacother., 4:889-901

Horinouchi H, Kubota K, Itani Het al., (2013): Short hydration in chemotherapy containing cisplatin $(\geq 75 \mathrm{mg} / \mathrm{m} 2)$ for patients with lung cancer: a prospective study. Jpn. J. Clin. Oncol.,43(11):1105-1109 .

Horobin RW and Bancroft JD (1998): Hematoxylin and eosin as an oversight stain. In: Trubleshooting Histology stains, $1^{\text {st }}$ ed., Churchill Livingstone Press, San Francisco, pp. 88- 93.

Hotta K, Takigawa N, Hisamoto-Sato A et al. (2013):Reappraisal of short-term low-volume hydration in cisplatin-based chemotherapy: results of a prospective feasibility study in advanced lung cancer in the Okayama Lung Cancer Study Group Trial 1002. Jpn. J. Clin. Oncol.,43:1115-1123.

Iezhitsa IN,Spasov AA,Kharitonova MV et al., (2011): Effect of magnesium chloride on psychomotor activity, emotional status, and acute behavioural responses to clonidine, d-amphetamine, arecoline, nicotine, apomorphine, and L-5hydroxytryptophan. Nutr. Neurosci.,14(1):1024.

Ikeguchi M, MichioMaeta $\mathrm{M}$ and Kaibara N (2000):Cisplatincombined with prostaglandine E1 chemotherapy in rat perotiniumcarcinomatosis. Int. J. Cancer: 88, 474-478.

James MF (2009): Magnesium: an emerging drug in anaesthesia. Br J Anaesth., 103(4):465-7.

Jo S K, Cho WY, Sung SA et al., (2005): "MEK inhibitor, U0126, attenuates cisplatin-induced renal injury by decreasing inflammation and apoptosis," Kidney International, 67(2): 458466.

Kannan K and Jain SK (2000):Oxidative stress and apoptosis. Pathophysiology, 7: 153-163 .

Kodama A, Watanabe $\mathrm{H}$ and Tanaka R (2014): "Albumin fusion renders thioredoxin an effective anti-oxidative and anti-inflammatory agent for preventing cisplatin-induced nephrotoxicity," Biochimica et Biophysica Acta,840: 1152-1162.

Kuhlmann MK, Burkhardt G and Köhler H (1997): "Insights into potential cellular mechanisms of cisplatin nephrotoxicity and their clinical application," Nephrology Dialysis Transplantation, 12(12): 2478-2480.

Lajer H, Kristensen M, Hansen HH et al.,(2005a): Magnesium and potassium homeostasis during cisplatin treatment. Cancer Chemother. Pharmacol.;55:231-6.

Lajer H, Kristensen M, Hansen HH et al.,(2005b): Magnesium depletion enhances cisplatininduced nephrotoxicity. Cancer Chemother. Pharmacol.,56:535-42.

Lajer Hand Daugaard G(1999): Cisplatin and hypomagnesemia. Cancer Treat. Rev.,25:47-58 .

Landon CD, Benjamin SE, Ashcraft KA et al., (2013): A role for the copper transporter Ctr1 in the synergistic interaction between hyperthermia and cisplatin treatment. Int. J. Hyperthermia 29: 528-538.

Launay-Vacher V, Rey JB,Isnard-Bagnis C et al., M. (2008):Prevention of cisplatin nephrotoxicity: State of the art and recommendations from the European Society of Clinical Pharmacy Special Interest Group on Cancer Care, Cancer Chemotherapy and Pharmacology, 61 (6): 903909.

Lebwohl D and Canetta R (1998): "Clinical development of platinum complexes in cancer therapy: an historical perspective and an update," European Journal of Cancer, 34( 10): 1522-1534.

Lee KW, Jeong JY and Lim BJ (2009): Sildenafil attenuates renal injury in an experimental model or rat cisplatin-induced nephrotoxicity Toxicology, 257: 137-143.

Leibbrandt ME, Wolfgang GH, MetzAL et al., (1995):Critical subcellular targets of cisplatin and related platinum analogs in rat renal proximal tubule cells, Kidney International, 48(3): 761-770.

Long S andRomani A (2014): Role of cellular magnesium in human diseases. Austin J.Nutr. Food Sci. 18; 2(10): 1051

Malpuech-Brugere C, Nowacki W, Daveau M et al., (2000): Inflammatory response following acute magnesium deficiency in the rat. Biochim. Biophys. Acta. 1501: 91-98.

Malpuech-Brugere C, Nowacki W,Gueux E et al., (1999): Accelerated thymus involution in magnesium-deficient rats is related to enhanced 
apoptosis and sensitivity to oxidative stress. $\mathrm{Br}$. J. Nutr., 81: 405-411.

Malvika H, Solanki, Prodyot K et al., ( 2015): Magnesium protects against cisplatin-induced acute kidney injury without compromising cisplatin-mediated killing of an ovarian tumor xenograft in mice.American Journal of Physiology - Renal Physiology, 309 (1): F35F47.

Mazur A, Maier JA, Rock E et al., (2007): Magnesium and the inflammatory response: potential physiopathological implications. Arch. Biochem. Biophys. 458: 48-56.

Megyesi J, Safirstein RL and Price PM (1998):PM: induction of p21WAF1/CIP1/SDI in kidney tubule cells affects the course of cisplatininduced acute renal failure, The Journal of Clinical Investigation, 101: 777-782.

Mezad D,Hallak M,Huleihel M et al., (2002): Intravenous magnesium sulphate effect on maternal serum and amniotic fluid cytokines levels in preterm labour patients. Magnes. Res., 15:247-252.

Miller RP, Tadagavadi RK, Ramesh G et al., (2010): Mechanisms of cisplatin nephrotoxicity. Toxins (Basel) 2: 2490-2518.

Mirkheshti A, Aryani MR, Shojaei P et al., (2012): The Effect of Adding Magnesium Sulfate to Lidocaine Compared with Paracetamol in Prevention of Acute Pain in Hand Surgery Patients Under Intravenous Regional Anesthesia (IVRA). Int. J. Prev. Med., 3(9):616-21.

Mochizuki M, Akagi K, Inoue K et al., (1998): A single dose toxicity study of magnesium sulfate in rats and dogs.Jtoxicol Sci.; 23 (1):31-5.

Moran SM and Myers BD (1985): Course of acute renal failure studied by a model of creatinine kinetics. Kidney Int.,27:928-937.

Muraki K, Kaida S, Ito T et al.,(2013): Magnesium premedication prevents Cisplatin-induced nephrotoxicity in patients with esophageal and hypopharyngeal cancer. Gan To Kagaku Ryoho.;40:743-747.

Muraki K, Koyama R, Honma Y et al., (2012): Hydration with magnesium and mannitol without furosemide prevents the nephrotoxicity induced by cisplatin and pemetrexed in patients with advanced non-small cell lung cancer. J. Thorac. Dis.,4:562-568.

Nasulewicz A, Zimowska W, Bayle D et al.,(2004):Changes in gene expression in the lungs of Mg-deficient mice are related to an inflammatory process. Magnes. Res., 17: 259263 .

NematbakhshM, Pezeshki Z, Eshraghi-Jazi F et al.,(2012): Vitamin E, vitamin C, or losartan is not nephroprotectant against cisplatin-induced nephrotoxicity in presence of estrogen in ovariectomizedrat model. Int J. Nephrol., 2012:284896.

Newman DJ and Price CP (1999): Renal function and nitrogen metabolites. In: burtis CA, Ashwood ER, editors.Text book of clinical chemistry. $3^{\text {rd }}$ edition, Philadelphia: W.B Standers Company. Pp: 1204-1207.

Nielsen FH(2010): Magnesium, inflammation, and obesity in chronic disease. Nutr. Rev. 68: 333340, 2010.

Nowacki W, Malpuech-Brugère $\mathrm{C}$, Rock E, et al.(2009):High-magnesium concentration and cytokine production in human whole blood model. Magnes. Res.,22:93-96

Ozkol H, Musa D,Tuluce Y et al., (2012): Ameliorative influence of Urticadioica L against cisplatininduced toxicity in mice bearing Ehrlich ascites carcinoma. Drug Chem. Toxicol., 35: 251-257.

Pabla N and Dong Z (2008): Cisplatin nephrotoxicity: mechanisms and renoprotective strategies. Kidney Int., 73: 994-1007.

Parlakpinar H, Sahna E, Ozer MK et al., (2002):Physiological and pharmacological concentrations of melatonin protect against cisplatin-induced acute renal injury. J. Pineal Res., 33, 161-166.

Pasetto LM, D'Andrea MR and BrandesAA (2006): The development of platinum compounds and their possible combination. Crit. Rev. Oncol. Hematol., 60: 59-75.

Pezeshki Z, Nematbakhsh M, Mazaheri S et al., (2012): Estrogen abolishes protective effect of erythropoietin against cisplatin-induced nephrotoxicity in ovariectomizedrats. ISRN Oncol.,2012:890310 .

Rana MA, Khan RA, Nasiruddin M et al.,(2016): Amelioration of cisplatin-induced nephrotoxicity by ethanolic extract of Bauhinia purpurea: An in vivo study in rats, 27 (1): 4148.

Ravi, R.; Somani, S. M. and Rybak L. P. (1995): Mechanism of cisplatin ototoxicity: antioxidant system. Pharmacol Toxicol. 76: 386-394 .

Rayssiguier Y and Mazur A(2005): Magnesium and inflammation: lessons from animal models. Clin. Calcium.,15(2):245-8.

Rayssiguier Y, Gueux E,Nowacki W et al., (2006): High fructose consumption combined with low dietary magnesium intake may increase the incidence of themetabolic syndrome by inducing inflammation. Magnes. Res., 19: 23743.

Rayssiguier Y, Libako P, Nowacki W et al., (2010): Magnesium deficiency and metabolic syndrome: stress and inflammation may reflect calcium activation. Magnes. Res., 23:73-80.

Rodriguez-Moran M and Guerrero-Romero F (2004): Elevated concentrations of TNF-alpha are related to low serum magnesium levels in obese subjects. Magnes. Res., 17: 189-96.

Romani A (2007): Regulation of magnesium homeostasis and transport in mammalian cells. Arch Biochem Biophys., 458:90-102.

Safirstein R, Miller P and Guttenplan JB (1984):Uptake and metabolism of cisplatin by rat kidney, Kidney International, 25(5): pp. 753-758. 
Sahu BD, Rentam KK, Putcha UK et al., (2011):Carnosicacid attenuates renal injury in an experimental model of rat cisplatin-induced nephrotoxicity. Food Chem. Toxicol., 49, 30903097.

Sanchez-Gonzalez PD, Lopez-Hernandez FJ, LopezNovoa J M et al., (2011):“An integrative view of the pathophysiological events leading to cisplatin nephrotoxicity," Critical Reviews in Toxicology, 41( 10): 803-821.,

Scanlan BJ, Tuft B, Elfrey JE et al.,(2007): Intestinal inflammation caused by magnesium deficiency alters basal and oxidative stress-induced intestinal function. Mol. Cell Biochem., 306: 59-69.

Shils ME (1999): Magnesium. In: Shils ME, Olson JA, Shike M, Ross AC, editors. Modern Nutrition in Health and Disease. Lippincott Williams \& Wilkins; New York. Pp. 169-192.

Shiraishi F, Curtis LM and Truong, L (2000): "Heme oxygenase-1 gene ablation or expression modulates cisplatin-induced renal tubular apoptosis," American Journal of Physiology: Renal Physiology, 278( 5): F726-F736.

Shogi T, Oono H, Nakagawa M et al., (2002): Effects of a low extracellular magnesium concentration and endotoxin on IL- $1 \beta$ and TNF- $\alpha$ release from, and mRNA levels in, isolated rat alveolar macrophages. Magnes. Res.,15:147-152.

Simonsen DG, Westover LM and Wertman M (1947):The determination of serum magnesium by the Molybdivandate method for phosphate. J. Biol. Chem., 169:39-47

Singh AK, Gaur S and Kumar R (2008):A randomized controlled trial of intravenous magnesium sulphate as an adjunct to standard therapy in acute severe asthma. Iran J. Allergy Asthma Immunol., 7(4):221-9.

Soltani N,Nematbakhsh M, Eshraghi-Jazi F et al., (2013): Effect of Oral Administration of Magnesium on Cisplatin-Induced Nephrotoxicity in Normal and StreptozocinInduced Diabetic Rats. Nephrourol. 5(4): 884890 .

Song Y, Li TY, van Dam RM et al.,(2007): Magnesium intake and plasma concentrations of markers of systemic inflammation and endothelial dysfunction in women. Am. J. Clin. Nutr. , 85: 1068-74.

Song Y, Ridker PM, Manson JE et al., (2005): Magnesium intake, C- reactive protein, and the prevalence of metabolic syndrome in middleaged and older U.S. women. Diabetes Care, 28: 1438-44.

SPSS Inc (2013): SPSS for windows, version 22.0. Chicago, SPSS Inc. http://www.unimunester.de/imperia/md/content/ziv/ser vice/softwr

e/spss/handbuecher/englisch/spss_brief_guide_22.0.pdf

Star RA (1998): Treatment of acute renal failure. Kidney Int., 54:1817-1831.

Stewart DJ, DulbergCS, Mikhael NZ et al., (1997): Association of cisplatin nephrotoxicity with patient characteristics and cisplatin administration methods. Cancer Chemother. Pharmacol., 40: 293-308 .

Sugimoto J, Romani AM,Valentin-Torres AM et al.,(2012): Magnesium Decreases Inflammatory Cytokine Production: A Novel Innate ImmunomodulatoryMechanism.J.Immunol., 188(12): 10

Sugiyama S, Hayakawa $M$, Kato $\mathrm{T}$ et al., (1989):“Adverse effects of anti-tumor drug, cisplatin, on rat kidney mitochondria: disturbances in glutathione peroxidase activity," Biochemical and Biophysical Research Communications, 159( 3): 1121-1127.

Thomas L (1998): clinical Laboratory Diagnostics. $1^{\text {st }}$ ed. Frankfurt: $1^{\text {st }}$ ed. Frankfurt: The book verlagsgesselschaft ,p 80-6.

Wang D and Lippard SJ (2005): Cellular processing of platinum anticancer drugs.Nat. Rev. Drug Discov., 4: 307-320.

Weglicki WB, Phillips TM, Freedman AM et al., (1992): Magnesium-deficiency elevates circulating levels of inflammatory cytokines and endothelin. Mol. Cell Biochem., 110:169-173.

Wei Q, Dong G, Franklin J et al.,(2007): "The pathological role of $\mathrm{Bax}$ in cisplatin nephrotoxicity," Kidney International, 72(1): 53-62.

Yang C, Kaushal V, Shah SV et al., (2008): Autophagy is associated with apoptosis in cisplatin injury to renal tubular epithelial cells, American Journal of Physiology: Renal Physiology, 294(4): F777F787.

Yokoo K, Murakami R, Matsuzaki T et al., (2009): Enhanced renal accumulation of cisplatin via renal organic cation transporter deteriorates acute kidney injury in hypomagnesemic rats. Clin. Exp. Nephrol.;13:578-84 .

Yoshida T, Martelli O,Mancuso A et al., (2007):Short hydration regimen and nephrotoxicity of intermediate to high-dose cisplatin-based chemotherapy for outpatient treatment in lung cancer and mesothelioma. Tumori.,93:138-144.

Yoshida T, NihoS, Toda M et al.,(2014): Protective effect of magnesium preloading on cisplatininduced nephrotoxicity: a retrospective study. Jpn. J. Clin.Oncol.,44:346-354 . 


\title{
الملخص العربيى
}

\section{التاثير المحتمل لمكملات الماغنسيوم على السمية الكلوية التيّي يسبيها السيسبلاتين فى ذكور}

\author{
وفاء ابراهيم سليمان ونشوى محمد محمد شلبى
}

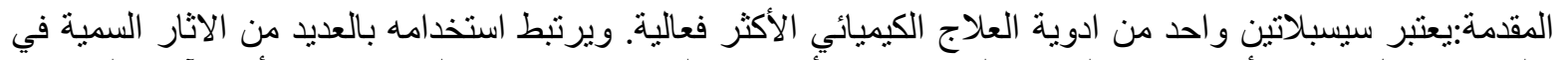

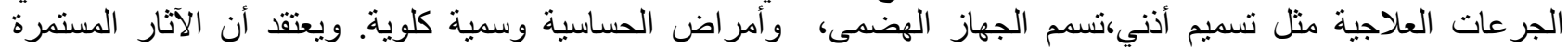

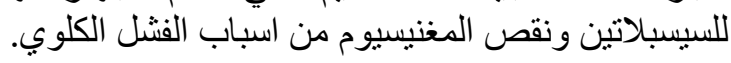

هدف البحث :تم اجراء هذا البحث لاراسة الاثار السامة لسيسبلاتين على الكلية وتقييم الآثار المحتملة للمكملات المغنيسيوم عليها فى ذكور الجرذان البيضاء

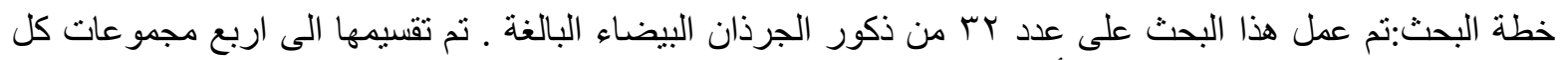

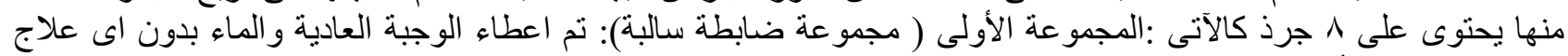

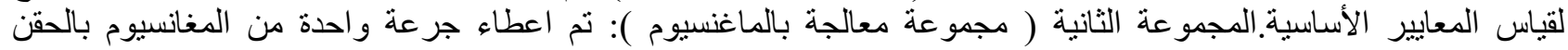

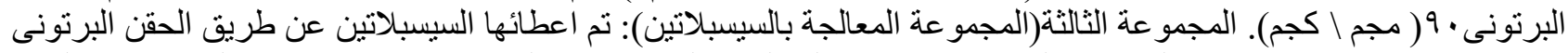

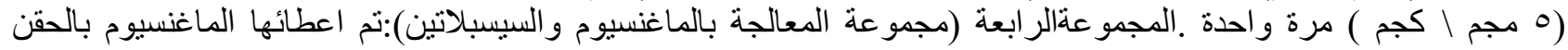

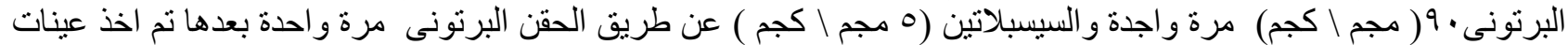

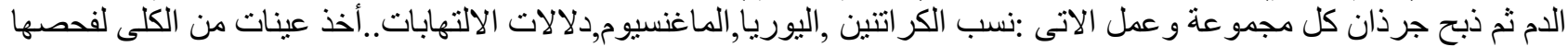

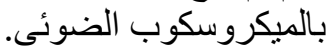

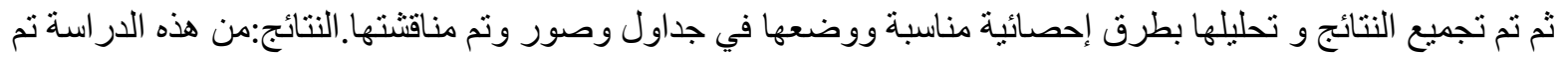

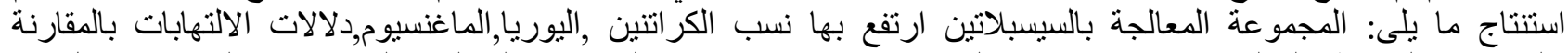

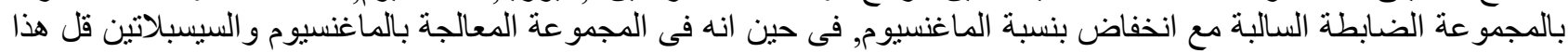

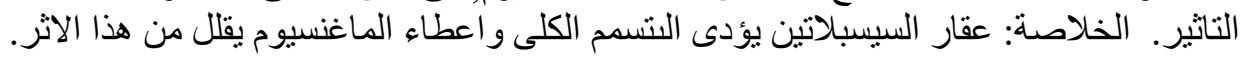
التوصيات: اجراء مزيد من الدراسات لمعرفة دور الماغنسيوم فى تقليل التسمم الكلوى الناجم عن استخدام عقار السيسبلاتين. 